\title{
Analysis of the Problems and Countermeasures of China's Green Credit
}

\author{
Xiaojie Wu, Xuehua Zhang* \\ School of Economics, Tianjin Polytechnic University, Tianjin, China \\ Email: *xuehua671231@163.com
}

How to cite this paper: $\mathrm{Wu}, \mathrm{X} . J$. and Zhang, X.H. (2018) Analysis of the Problems and Countermeasures of China's Green Credit. Journal of Geoscience and Environment Protection, 6, 111-119. https://doi.org/10.4236/gep.2018.66009

Received: May 9, 2018

Accepted: June 24, 2018

Published: June 27, 2018

Copyright $\odot 2018$ by authors and Scientific Research Publishing Inc. This work is licensed under the Creative Commons Attribution International License (CC BY 4.0).

http://creativecommons.org/licenses/by/4.0/

\begin{abstract}
At present, China's green credit market is the most important channel for green financing and has a great influence on the development of China's green finance. Based on the collection and arrangement of the related data and information, the paper points out the main problems which is existing in China's green credit by figures and examples from aspects of detail standards of policies, the matching level between deposits and loans and the management ability of avoiding environmental risk. Furthermore, the paper puts forward corresponding countermeasures of the problems.
\end{abstract}

\section{Keywords}

Green Credit, Environmental Financial Policies, Environmental Risk Management, Commercial Banks

\section{Introduction}

Green credit originates from Western countries. With the rise of public campaigns such as environmental protection and human rights, banks in Western countries have to face the risk of the project being stranded due to customer environmental problems and the risk of affecting their reputation or even losing other customers [1]. In order to avoid these risks and achieve their own sustainable development, banks have to carry out green credit. In 2003, 10 banks such as Citibank, Barclays Bank and ABN AMRO announced the implementation of the "Equator Principles" (EPs), which formally incorporated the concept of green finance into a standard bank risk management framework [2]. At present, the "Equator Principles" has become the industry benchmark for international banks to practice green credit. Different from other countries' "bottom-up" approach, the development of green credit in China began with the introduction of 
relevant environmental financial policies. In 2012, the China Banking Regulatory Commission formulated and issued the "Green Credit Guidelines," which is a key step in the development of China's green finance, and China's green credit market has entered a period of rapid development.

Until now, the academic community does not have a unified interpretation of the definition of green credit. Therefore, according to the requirements in the "Green Credit Guidelines", the core document of China's green credit system, this paper summarizes the connotation of green credit as follows. First of all, banks need to strengthen the credit support for the green economy, low-carbon economy and circular economy. Second, banks need to strengthen the management of environmental and social risks. Third, banks should pay attention to their own environmental and social performance, and achieve their own green development goal. In fact, commercial banks' implementations of green credit not only have social benefit of protecting the environment, but also have great significance for their own development. For example, they can effectively prevent credit risks and can strengthen effective cooperation with foreign commercial banks. Although China's green credit is developing rapidly, many problems remain to be solved. Therefore the objective of this paper is to find out the current problems of China's green credit and make green credit better serve environmental protection.

The research on green credit in other countries mainly focuses on the significance of banks in developing green credit [3] [4] [5] and how banks should conduct environmental risk management [6] [7]. Chinese scholars have already conducted some research on the problems of China's green credit [8] [9] [10]. However, few studies have used specific examples to illustrate the problems of China's green credit. The novelty of this paper is to illustrate the problems of China's green credit through specific examples and put forward some innovative suggestions.

\section{The Problems of China's Green Credit}

\subsection{Insufficient Detail Standards of Environmental Financial Policies}

China's environmental financial policies are macro-instructive, detail standards of environmental financial policies are insufficient. In this case, banks are given opportunities to provide loans to polluting companies, which seriously hinder the development of China's green credit.

With the continuous improvement of China's green credit system, China's green credit has a relatively complete policy framework and statistical system. However, China's environmental financial policies are macro-instructive. They do not have very clear provisions on the standards involved in green credit, nor do they have detailed implementation requirements [11]. Therefore, the detail standards for the implementation of green credit by banks in China are set by themselves, which gives banks great autonomy. 
According to the requirements of environmental financial policies, banks must not provide loans to companies that pollute the environment. These requirements have reduced banks' loan customers to a certain extent, and have affected banks' current profits. Because detail standards of environmental financial policies are insufficient, banks are given opportunities to find policy loopholes and provide loans for polluting companies. For example, the case of Kunming Power Plant pollution is a typical case. Kunming Power Plant was penalized by the environmental protection agency for exceeding the NOx emission concentration in 2013. Since Kunming Power Plant is a state-owned company and the company's financial performance had been good, banks were profitable for providing loans to it. Therefore, during the period when the company polluted the environment, the Bank of Communications had promised to issue 60 million loans to this company. After the first batch of loans of 30 million, the bank stopped its second loan due to increasingly stringent inspections by the environmental protection agency [12]. In this case, it was precisely because of the insufficient detail standards of environmental financial policies that caused Bank of Communications to provide loans to this polluting company, which seriously hinder the development of China's green credit. Therefore, it is particularly important to formulate specific and enforceable implementation policies.

\subsection{Mismatch of Deposits and Loans}

Most banks' deposits are short-term. If banks provide large amounts of loans for long-term green projects, they will bring liquidity risk to banks, which is not conducive to the sustainable development of banks.

According to the green credit statistics system formulated by the China Banking Regulatory Commission, China's green credit assets include two major components. The first is credit support for production and manufacturing of three strategic emerging industries, which include energy-saving and environmental protection, new energy and new energy vehicles. The second is credit support for twelve types of energy-saving and environmental protection projects and services. Green credit financing balance is the sum of the amount of these green credit assets in banks. The data on green credit financing balance of China's 21 major banks provided by the China Banking Regulatory Commission are shown in Figure 1.

According to the data in Figure 1, the data shows that the balance of China's 21 banks' green credit financing from 2013 to 2017 is relatively large and continues to increase. In China, green credit is still the main green financing channel, accounting for more than $95 \%$ of total green financing [13]. These show that China's green credit market is booming. However, banks should pay more attention to their own liquidity risks.

Some of the green credit projects are long-term green projects, such as water pollution control, solid waste treatment and green transportation, while most of the deposits absorbed by banks are short-term deposits. It is difficult for banks 


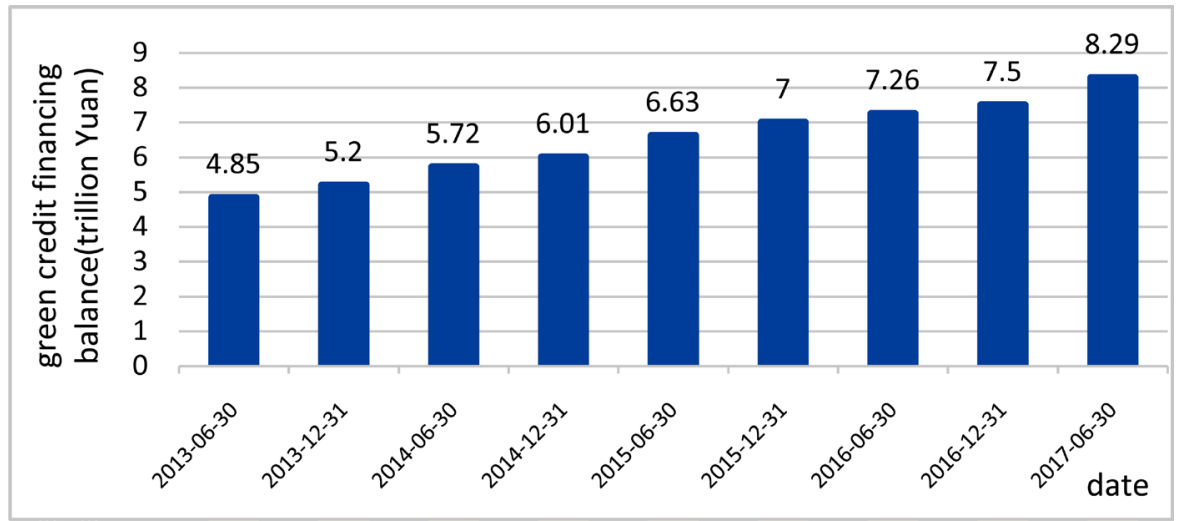

Figure 1. China's 21 major banks' green credit financing balance.

to provide sufficient long-term loans in order to avoid excessive mismatch between deposits and loans [14]. If commercial banks provide large amounts of loans for long-term green projects, it will lead to shortage of funds and trigger liquidity risks, which is not conducive to the health and sustainable development of commercial banks. Take Nanchang subway construction as an example. According to relevant news reports, the financing of all subway lines in Nanchang has the participation of 25-year syndicated loans. Bank loans are the most important financing channel for China's subway construction, with 25-year project loans as the main ones [15]. According to the annual reports of China's 21 major commercial banks, their time deposits over five years account for less than one-thousandth of all deposits. In this case, a single bank does not have the ability to provide large amounts of long-term loans, so most banks in China used syndicated loans to lend to subway construction projects. Therefore, maturity mismatch of deposits and loans will limit banks' investment in long-term green projects, which is one of the obstacles to the expansion of China's green credit scale.

\subsection{Insufficient Ability of Banks' Environmental Risk Management}

The insufficient ability of environmental risk management in many banks is caused by the shortage of professional talents and professional institutions. Therefore, banks are more reliant on the environmental impact assessment of construction projects when carrying out environmental risk management, but this assessment cannot meet the needs of banks [16].

According to the data provided by the China Banking Regulatory Commission, due to the impact of the macro economy in recent years, banks' non-performing loan rate has risen, and the non-performing loan rate of green credit is no exception. However, the credit quality of China's green credit is relatively good, and the non-performing rate is far below the overall credit's non-performing loan rate (Figure 2).

The data shows that most green credit assets are high-quality bank credit assets and help reduce non-performing loan rate of banks. Therefore, commercial 


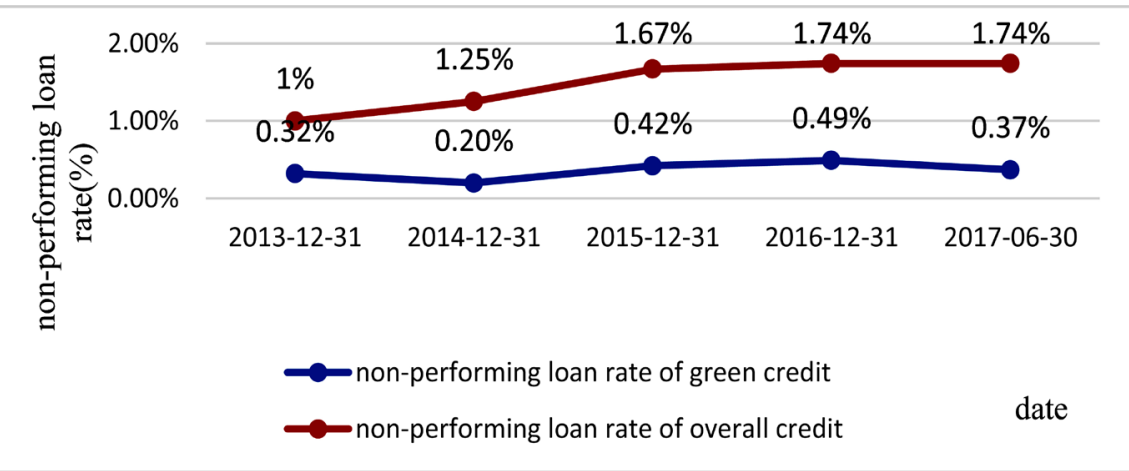

Figure 2. Comparison between non-performing loan rate of green credit and non-performing loan rate of overall credit in China.

banks launching green credits and conducting environmental risk management can help reduce bank credit risk. Among the commercial banks in China, only Industrial Bank has a professional approval department for environmental risk. Many banks in China do not have enough relevant talents, institutions are not in place, and the ability to manage environmental risks is insufficient. Therefore, when conducting environmental risk management, banks mainly depend on the environmental impact assessment of construction projects.

However, this assessment cannot fully meet the needs of banks. The reasons are as follows. Firstly, the environmental impact assessment of construction projects is more emphasis on pre-assessment, which cannot satisfy banks' need for continuous attention from the borrowers' environmental risks. Secondly, the environmental impact assessment of construction projects lays more emphasis on technology assessment, but banks focus mainly on the impact of environmental and production safety on business operations and financial performance [17]. For example, Dongling Group lead pollution incident is a very classic case. In 2008, the Bank of China issued a loan of 450 million yuan to Dongling Group, a metal smelting company in Shaanxi. As Bank of China over-reliance on the environmental impact assessment of construction projects, the bank did not clearly identify the company's environmental risks. In 2009, Dongling Group was punished for excessive discharge of lead and caused serious harm to the health of local children [18]. This incident has caused a great social impact. The local Bank of China was also involved, and posed a great risk to the recovery of bank loans. Therefore, over-reliance on the environmental impact assessment of construction projects is not conducive to banks' implementation of environmental risk management and will increase banks' credit risk.

\section{Corresponding Countermeasures and Suggestions}

\subsection{Strengthen the Construction of Relevant Environmental Financial Policies}

Specific and clear green credit standards and requirements are the preconditions for banks to effectively conduct green credit business. The current environmen- 
tal financial policies relevant to green credit provide relatively broad requirements, and the detail standards are insufficient. The government should strengthen the construction of the environmental financial policies and provide detailed green credit standards and requirements.

First, standards related to green credit should be refined. The government can draw on the relevant requirements of the Equator Principles and propose specific quantifiable standards for all aspects of China's green credit. Improving the existing green credit standards system, and subdividing them according to the green degree of the project (such as dark green, green, light green) so as to avoid the "washing green" behavior that companies use to defraud green credit. Second, clear banks' environmental legal responsibility. Environmental financial policies should follow the "user pays" approach and use legislation to clearly stipulate the responsibilities and powers of stakeholders such as governments, enterprises, and commercial banks in the development of green economy [19]. The government should also strengthen the monitoring of the bank's implementation of green credit, and impose severe penalties on banks that violate the requirements of green credit related policies. Third, strengthen cooperation between banks and environmental protection agencies. Improve the communication channels between banks and environmental protection agencies, make full use of the professional advantages of both, and work out a set of uniform evaluation standards system suitable for banks.

\subsection{Strengthen the Development of Green Credit Asset Securitization}

Credit asset securitization is one of the important forms of commercial banks' financial innovation. The securitization of green credit assets has the following three advantages. First, after asset securitization of green credit, banks can convert short-term bank deposit funds into long-term securities investment funds for investors, and solve the problem of commercial banks' green credit maturity mismatch of deposits and loans. Second, after commercial banks proceed with asset securitization, their green credit loans are no longer subject to regulatory restrictions on central bank deposit reserves and loan-to-deposit ratios, which is conducive to expanding the scale of commercial banks green industry financing. Third, the securitization of green credit assets has also provided a bridge for green credit projects and investors in the securities market, facilitating more investors to finance green projects. Therefore, securitization of green credit assets will not only reduce the liquidity risk exposure caused by banks' mismatch of deposits and loans, which increase the safety and liquidity of commercial banks, but also expanded the market's financing scale for green projects.

In order to more effectively carry out the securitization of green credit assets, the government should do a good job of linking green financial products. The first is to strengthen the coordination of green credit standards and green securities issuance standards so as to avoid the embarrassment caused by inconsistent 
standards. In addition, government should establish a Green Credit ABS (Asset Backed Securitization) Bond audit fast track to improve the convenience of issuance of Green Credit ABS Bonds. Third, a special sign can be added to the name of the green credit asset securitization product, so that investors can intuitively see and increase product promotion.

\subsection{Strengthen the Dynamic Assessment of Environmental Risks and Actively Carry Out Environmental Risk Stress Tests}

At present, the environmental risk management of commercial banks in China mainly depend on the environmental impact assessment of construction projects, but the environmental impact assessment of construction projects can not meet the needs of commercial banks. In order to make up for the limitations of environmental impact assessment of construction projects, this paper proposes the following two countermeasures.

Firstly, commercial banks should strengthen dynamic assessment of corporate environmental risks. Based on the environmental impact assessment of the construction projects and the information provided by companies and conducting field investigations, banks can obtain first-hand companies' environmental protection information. And then, the information should be handed over to banks' environmental risk management department to conduct a rigorous review of the environmental issues and environmental risks faced by companies. In the loan, banks should strengthen the monitoring of the implementation of environmental protection measures in companies. Banks can obtain real-time monitoring information through field surveys, inquiries from nearby residents, and local environmental protection agencies. If the company does not strictly implement the corresponding environmental protection measures in the loan, banks should immediately stop the issuance of the loan and include the company in the "black list" of bank credit. After the completion of the project, banks should make a corresponding summary of the loan, summarize the problems and shortcomings of the loan, and prepare for the next better development of the green credit business.

In addition, commercial banks should also actively carry out stress tests on environmental risks. Banks carrying out environmental stress tests have the potential to become an important tool for promoting the development of green finance in the future. The environmental risk stress test is mainly based on the introduction of corresponding environmental protection policies, laws and regulations, setting up different scenarios for scenario analysis, and analyzing the effects of changes in environmental protection policies and laws on financial status of the company. Then banks calculate the non-performing loan rate of the company based on the relationship between the financial status of the company and the non-performing loan rate of the company. Through stress tests, banks can estimate the future non-performing loan rate of some industries with high environmental risks and obtain a quantitative relationship between environ- 
mental risks and future credit risks, so that banks can re-examine their asset allocation and encourage them to reduce pollution industry loans, while increasing funding for the green industry [20].

These countermeasures and suggestions not only regulate banks' green credit business, effectively prevent environmental risks, but also provide incentives for banks to develop green credit business, which is conducive to make green credit better serve environmental protection.

\section{Conclusions}

Different from other countries, China's green credit started with the introduction of relevant environmental financial policies. With the support of environmental financial policies and the efforts of banks, China's green credit market has achieved remarkable results. However, China's green credit market still has problems that restrict its development. Therefore the objective of this paper is to find out the current problems of green credit and make green credit better serve environmental protection. Based on the collection and arrangement of the related data and information, the paper points out the main problems which is existing in China's green credit by figures and examples from aspects of detail standards of policies, the matching level between deposits and loans and the management ability of avoiding environmental risk. Furthermore, in response to the corresponding problems, the paper puts forward countermeasures such as strengthening the construction of relevant policies, strengthening the development of green credit asset securitization, strengthening the dynamic assessment of environmental risks, and actively carrying out environmental risk stress tests.

The paper believes that relying solely on policies or banks is not enough to solve these problems. Only through mutual cooperation between policies and banks, China's green credit can better serve environmental protection and promote sustainable economic development.

\section{Acknowledgements}

This paper is supported by the Philosophy and Social Science Planning Project of Tianjin (TJLJ15-008).

\section{References}

[1] Ma, J., Zhou, Y.Q. and Yin, H. (2017) International Case Studies of Green Finance Development. China Financial Publishing House, Beijing.

[2] Li, L.J. (2015) The Enlightenment of "Equator Principles" to China's Green Finance Construction. Modernization of Management, 35, 118-120.

[3] Bert, S. and Lammertjan, D. (2007) Are Bank that Adopted the Equator Principles Different from Non-Adopters. World Development, 35, 1307-1328. https://doi.org/10.1016/j.worlddev.2006.10.013

[4] Watchman, P. (2005) Beyond the Equator. Environmental Finance, 6, 16-17.

[5] Chami, R. and Cosimano, T.F. (2002) Managing Ethical Risk: How Investing in 
Ethical Adds Value. Journal of Banking and Finance, 26, 1697-1781. https://doi.org/10.1016/S0378-4266(02)00188-7

[6] Olaf, W. (2005) Sustainability Benchmarking of European Banks and Financial Service Organizations. Corporate Responsibility and Environmental Management, 12, 3-87.

[7] Paul, T. and Christopher, J.C. (2004) What Drives Bank Competition Some International Evidence. Journal of Money Credit and Banking, 10, 11-56.

[8] Liu, C.Y. (2012) Research on the Development of Green Credit in China. Taxation and Economy, 1, 29-32.

[9] Mao, S.Q. (2012) Analysis on Green Credit of Domestic Commercial Banks. Times Finance, 27, 201.

[10] Shen, Y.H. (2013) Research on the Development of Green Credit in China's Banking Industry. Value Engineering, 32, 178-179.

[11] Guang, L., Xu, Q. and Wang, H. (2017) Research on the Green Credit Development Strategy of Commercial Banks in China Based on the "Equator Principles". Wuhan Finance, 10, 54-60.

[12] Yu, X.G. (2014) China Banking Environment Record 2014. Yunnan Science \& Technology Press, Kunming.

[13] Lu, Z.W. and Tang, W.Q (2017) An Overview of China's Green Financial Market in 2017. http://greenfinance.xinhua08.com/a/20180108/1744086.shtml

[14] Ma, J. (2016) Green Finance: China and G20. Overseas Investment \& Export Credits, 6, 3-10.

[15] Li, M.Z. (2016) An Analysis of Investment and Financing Paths During Rapidly Expanding Urban Rail Transit Construction. Traffic Investment and Financing, 9, 38-43.

[16] Lan, H. (2012) Environmental Risk Management of Commercial Banks. China Financial Publishing House, Beijing.

[17] Hu, N.W. and Cao, D.W. (2011) Green Credit and Commercial Bank Environmental Risk Management. Economic Issues, 3, 103-107.

[18] Yu, X.G. (2009) China Banking Environment Record 2009. Yunnan Science \& Technology Press, Kunming.

[19] Zhang, C.H., Zhang, L.P., Chen, N., Zhang, Y. and Li, S.F. (2014) Strengthen Policy Guidance and Promote the Rapid Development of China's Green Credit. Development Research, 7, 17-21.

[20] Ma, J. (2017) Ten Areas of China's Green Finance Development. Wuhan Finance, 1, $10-14$. 